\title{
$T$ cell activation causes diarrhea by increasing intestinal permeability and inhibiting epithelial $\mathrm{Na}^{+} / \mathrm{K}^{+}$-ATPase
}

\author{
Mark W. Musch, ${ }^{1}$ Lane L. Clarke, ${ }^{2}$ Daniel Mamah, ${ }^{3}$ Lara R. Gawenis, ${ }^{2}$ Zheng Zhang, ${ }^{4}$ \\ William Ellsworth, ${ }^{3}$ David Shalowitz, ${ }^{3}$ Navdha Mittal, ${ }^{3}$ Petros Efthimiou, ${ }^{3}$ \\ Ziad Alnadjim, ${ }^{3}$ Steve D. Hurst, ${ }^{5}$ Eugene B. Chang, ${ }^{1}$ and Terrence A. Barrett ${ }^{3}$
}

${ }^{1}$ The Martin Boyer Laboratories, Department of Medicine, University of Chicago, Chicago, Illinois, USA
2Dalton Cardiovascular Research Center, University of Missouri, Columbia, Missouri, USA
${ }^{3}$ Division of Gastroenterology and Hepatology, Department of Medicine, and
${ }^{4}$ Department of Surgery, Northwestern University Medical School, Chicago, Illinois, USA
${ }^{5}$ Corgentech Research, Palo Alto, California, USA

Inflammatory bowel disease (IBD) is associated with mucosal T cell activation and diarrhea. We found that $\mathrm{T}$ cell activation with anti-CD3 $\mathrm{mAb}$ induces profound diarrhea in mice. Diarrhea was quantified by intestinal weight-to-length (wt/l) ratios, mucosal $\mathrm{Na}^{+} / \mathrm{K}^{+}$-ATPase activity was determined and ion transport changes were measured in Ussing chambers. Anti-CD3 $\mathrm{mAb}$ increased jejunal $\mathrm{wt} / \mathrm{l}$ ratios by more than $50 \%$ at 3 hours, returning to base line after 6 hours. Fluid accumulation was significantly reduced in TNF receptor-1 (TNFR-1 ${ }^{-/}$), but not IFN- $\gamma$ knockout mice. Anti-CD3 mAb decreased mucosal $\mathrm{Na}^{+} / \mathrm{K}^{+}$-ATPase activity, which was blocked by anti-TNF $\mathrm{mAb}$ and occurred to a lesser degree in TNFR-1 $1^{-/}$mice. Neither $\alpha$ nor $\beta$ subunits of $\mathrm{Na}^{+} / \mathrm{K}^{+}$-ATPase decreased in abundance at 3 hours. Intestinal tissue from anti-CD3-treated mice exhibited increased permeability to mannitol at 1 hour and decreases in electroneutral $\mathrm{Na}^{+}$absorption, $\mathrm{Na}^{+}$-dependent glucose absorption, and cAMP-stimulated anion secretion at 3 hours. Furthermore, enteral fluid accumulation was observed in $\mathrm{CFTR}^{-/-}$mice, indicating a minor role of active anion secretion. These data suggest that diarrhea in IBD is due to TNF-mediated malabsorption rather than to secretory processes. T cell activation induces luminal fluid accumulation by increasing mucosal permeability and reducing epithelial $\mathrm{Na}^{+} / \mathrm{K}^{+}$-ATPase activity leading to decreased intestinal $\mathrm{Na}^{+}$and water absorption.

J. Clin. Invest. 110:1739-1747 (2002). doi:10.1172/JCI200215695.

\section{Introduction}

Diarrhea is a common clinical feature of immunemediated bowel dysfunction. Disordered immune cell activation leads to bowel dysfunction via multiple pathways. In disorders associated with cellular inflammation, arachidonic acid metabolites, reactive oxygen radicals, cytokines, and products of enteric nerves are proposed to mediate diarrhea (reviewed in ref. 1). However, despite the abundance of experimental data regarding diarrhea associated with intestinal inflammation, it has been difficult to target a specific pathway for therapeutic intervention until recently. Results of clinical trials indicate that blockade of the inflammatory mediator TNF effectively reduces disease parameters, including diarrhea, in patients with Crohn disease (2-4). In fact, TNF is detected at

Received for publication April 15, 2002, and accepted in revised form October 22, 2002.

Address correspondence to: Terrence A. Barrett, Northwestern University Medical School, 303 East Chicago Avenue, Med/GI S208, Chicago, Illinois 60611, USA. Phone: (312) 503-0293; Fax: (312) 908-6192; E-mail: tabarrett@northwestern.edu. Mark W. Musch and Lane L. Clarke contributed equally to this work. Conflict of interest: The authors have declared that no conflict of interest exists.

Nonstandard abbreviations used: inflammatory bowel disease (IBD); TNF receptor-1 (TNFR-1); weight-to-length [ratio] (wt/l). high levels in tissues in several disorders characterized by mucosal inflammation and diarrhea, including Crohn disease (3,5-8), graft-versus-host disease (9), small-bowel allograft rejection (10), and celiac sprue (11). Relatively high levels of TNF have been detected in the stool of patients with diarrheal illnesses due to enteric infections $(12,13)$. More directly, a phase I study of recombinant TNF infusion in human malignancies found that TNF caused watery diarrhea along with fever, chills, and flu-like symptoms (14). Taken together, these findings suggest that TNF is an important mediator of diarrhea.

A variety of mechanisms are involved in regulating transport of electrolytes and water in the enterocyte. Increased chloride $\left(\mathrm{Cl}^{-}\right)$secretion (in crypts) and decreased sodium $\left(\mathrm{Na}^{+}\right)$absorption (in villus tips) both lead to net fluid loss from the small intestine. Both $\mathrm{Cl}^{-}$ secretion and $\mathrm{Na}^{+}$absorption are dependent on the function of $\mathrm{Na}^{+} / \mathrm{K}^{+}$-ATPase in the basolateral membrane. Sodium absorption is abolished and $\mathrm{Cl}^{-}$secretion reduced when $\mathrm{Na}^{+} / \mathrm{K}^{+}$-ATPase is inhibited (15). Not surprisingly, multiple groups have detected decreased activity of epithelial $\mathrm{Na}^{+} / \mathrm{K}^{+}$-ATPase in inflamed tissue in inflammatory bowel disease (IBD) (16-18) and infectious enteritis (19). These findings suggest that downregulation of $\mathrm{Na}^{+} / \mathrm{K}^{+}$-ATPase is an important factor in the diarrhea associated with intestinal inflammation. 
To investigate the mechanism(s) involved in diarrhea associated with immune-mediated bowel disorders, we used a model for activating $\mathrm{T}$ cells in vivo with injection of anti-CD3 mAb. Anti-CD3 mAb cross-links $\mathrm{T}$ cell receptors and activates $T$ cells when administered systemically or when provided to cells in vitro $(20,21)$. Infusion of the murine monoclonal anti-human CD3 $\mathrm{mAb}$ OKT3 is used in the treatment of human organ rejection, as relatively high-dose stimulation depletes T cells, resulting in its immunosuppressive effects. However, prior to $\mathrm{T}$ cell depletion, a self-limited clinical syndrome of fever, hypotension, and diarrhea occurs due to the release of cytokines (TNF, IFN- $\gamma$, and IL-2) detected in the serum within hours of the first injection (20). A recent study by Radojevic et al. (22) reported that systemic anti-CD $3 \mathrm{mAb}$ administration in mice induced transient diarrhea within 4 hours of injection and increased the base-line jejunal short-circuit current $\left(I_{\mathrm{sc}}\right)$ measured 20 hours after injection. However, it remains unclear what mediators induced by anti-CD3 mAb were involved in intestinal fluid losses. In the current study, we used anti-CD3 mAb injection to study the mechanism(s) involved in T cell-induced diarrhea. We found that anti-CD3 mAb induced a transient watery diarrhea mediated by TNF. Furthermore, we found that $\mathrm{T}$ cell-induced TNF reduced the enzyme activity of $\mathrm{Na}^{+} / \mathrm{K}^{+}$-ATPase in epithelial cells without affecting protein levels. Evaluation of mouse intestine mounted in Ussing chambers revealed increased permeability and a profound antiabsorptive effect of $\mathrm{T}$ cell activation. Taken together, these data suggest that TNF-mediated downregulation of $\mathrm{Na}^{+} / \mathrm{K}^{+}$-ATPase contributes to intestinal fluid losses in patients with immune-mediated bowel disorders by impairing electrolyte absorption.

\section{Methods}

Mice. C57BL/6 mice were obtained from the National Cancer Institute (Frederick, Maryland, USA). Mice deficient in TNF receptor-1 (TNFR-1; p55) and mice deficient in IFN- $\gamma$, on C57BL/ 6 background, were obtained from The Jackson Laboratory (Bar Harbor, Maine, USA). CFTR-deficient mice were provided by Laboratory Animal Resources of Dalton Cardiovascular Research Center (University of Missouri-Columbia). B6.129 mice were obtained from The Jackson Laboratory. For all experiments, female mice were primarily used, at 6-8 weeks of age. Similar results were obtained in a limited number of male mice. Mice were maintained under specific pathogen-free conditions in the Veterans Administration Lakeside Medical Center (Medical Science Building, Northwestern University) and Dalton Cardiovascular Research Center (University of Missouri-Columbia). All animal studies were approved by the Center for Experimental Animal Resources of Northwestern University and the University of Missouri Animal Care and Use Committee.

Antibodies and cytokines. Hamster anti-murine CD3 $\mathrm{mAb}(2 \mathrm{C} 11)$ and control hamster mAb (UC8-1B9) were obtained from Pharmingen (San Diego, California,
USA). Anti-TNF (XT22), anti-IFN- $\gamma$ (XMG-1.2), and isotype-matched rat control (GL113) mAb's were purified from ascites. Antibody was purified over a protein $\mathrm{G}$ column (Amersham Pharmacia Biotech, Piscataway, New Jersey, USA). Highly purified murine TNF was purchased from PeproTech Inc. (Rocky Hill, New Jersey, USA). Murine IFN- $\gamma$ was purchased from Life Technologies Inc. (Gaithersburg, Maryland, USA). For all reagents, endotoxin levels were tested using the Limulus amoebocyte lysate assay (BioWhittaker Inc., Walkersville, Maryland, USA) and contained less than 0.1 endotoxin unit $/ \mathrm{ml}$.

Enteropooling. To determine the time course of intestinal fluid accumulation following $\mathrm{T}$ cell activation, C57BL/ 6 mice were sacrificed 1, 3, 6, and 9 hours following intraperitoneal injection of $0.2 \mathrm{mg}$ anti-CD3 (2C11) mAb. For other experiments, mice were sacrificed 3 hours after intraperitoneal injection of $0.2 \mathrm{mg}$ of either anti-CD3 or control hamster mAb (UC8-1B9). Anti-TNF (XT22, $0.5 \mathrm{mg}$ ), anti-IFN- $\gamma$ (XMG-1.2, 0.2 $\mathrm{mg}$ ), or control (GL113) mAb's were administered intraperitoneally 2 hours before $\mathrm{T}$ cell activation. TNF was given intraperitoneally in a range of doses as indicated, and IFN- $\gamma$ was given intraperitoneally in a dose of $10,000 \mathrm{U}$. TNF- and IFN- $\gamma$-treated mice were sacrificed 3 hours after respective treatments.

To quantify the diarrhoegenic activity of in vivo $\mathrm{T}$ cell activation as well as to test agents that may block this effect, we measured the weight-to-length (wt/l) ratios of isolated sections of jejunum. The technique was adapted from previously used methods for assessing the accumulation of fluid into the small intestine, called "enteropooling." Enteropooling is the difference between the fluid being excreted into the lumen and the fluid absorbed (23). The wt/l ratio is a measure of the weight of a section of small bowel in milligrams divided by the length in centimeters. For each measurement, mice were sacrificed at the time interval indicated. Mice were fasted overnight but allowed to drink water ad libitum. The intestine was moved as little as possible so as not to disturb fluid in the lumen. Three jejunal segments $(3-6 \mathrm{~cm})$ that could be readily excised were carefully isolated, ligated securely at both ends with equivalent lengths of 4-0 nylon, and removed. Adherent mesentery was cut off, and segments were weighed, their lengths measured, and their wt/1 ratios determined.

$\mathrm{K}^{+}$-stimulated phosphatase measurement of $\mathrm{Na}^{+} / \mathrm{K}^{+}$-ATPase. The $\mathrm{Na}^{+} / \mathrm{K}^{+}$-ATPase activity was measured as described previously (24). Ten-centimeter segments of jejunum were rinsed in ice-cold saline, and mucosae were scraped off using glass slides. Intestinal scrapings were homogenized in lysis buffer $(10 \mathrm{mM}$ Tris [pH 7.4], $3 \mathrm{mM}$ EDTA, $1 \mathrm{mM}$ PMSF, and $10 \mu \mathrm{g} / \mathrm{ml}$ each of pepstatin, leupeptin, aprotinin, and antipain). Nuclei were pelleted $\left(500 \mathrm{~g}, 2\right.$ minutes, $\left.4^{\circ} \mathrm{C}\right)$, and then microsomal membranes were pelleted $\left(100,000 \mathrm{~g}, 20\right.$ minutes, $\left.4^{\circ} \mathrm{C}\right)$. Membranes were resuspended, and aliquots were added to triplicate tubes of either $\mathrm{K}^{+}$or $\mathrm{Na}^{+}$buffer with the $\mathrm{Na}^{+} / \mathrm{K}^{+}$-ATPase substrate $p$-nitrophenol phosphate. Samples were incubated at $37^{\circ} \mathrm{C}$ for 1 hour, and the 
reaction was stopped by addition of $10 \%$ trichloroacetic acid. After addition of $1 \mathrm{~N} \mathrm{NaOH}$ to neutralize, the samples were centrifuged for 15 minutes. Absorbances were read at $410 \mathrm{~nm}$ and compared with standard $p$-nitrophenol (PNP). Protein in an aliquot was measured by the bicinchoninic acid protein assay.

Western blot of $\mathrm{Na}^{+} / \mathrm{K}^{+}$-ATPase subunit. An aliquot of microsomal membranes isolated above was used for determination of the $\alpha$ and $\beta$ subunits of $\mathrm{Na}^{+} / \mathrm{K}^{+}$-ATPase. Protein was solubilized in Laemmli-SDS stop solution, analyzed on $10 \%$ SDS-PAGE, and immediately transferred to a PVDF membrane. Blots were blocked with $5 \%$ milk in Blotto buffer $(150 \mathrm{mM} \mathrm{NaCl}, 5 \mathrm{mM} \mathrm{KCl}$, and $10 \mathrm{mM}$ Tris [pH 7.4], with $0.5 \% \mathrm{vol} / \mathrm{vol}$ Tween-20) and incubated overnight at $4^{\circ} \mathrm{C}$ with $\mathrm{mAb}$ 's to either $\alpha$ (clone C464.6) or $\beta$ (clone 464.8; Upstate Biotechnology Inc., Lake Placid, New York, USA) subunits of rabbit $\mathrm{Na}^{+} / \mathrm{K}^{+}$-ATPase (crossreactive to murine epitopes). Blots were washed, incubated with horseradish peroxidase-conjugated anti-mouse IgG (Jackson ImmunoResearch Laboratories Inc., Westgrove, Pennsylvania, USA), and developed using an enhanced chemiluminescence system (SuperSignal; Pierce Chemical Co., Rockford, Illinois, USA).

In vitro isotopic flux and bioelectric measurements. Sections of mid-jejunum were excised from wild-type and $\mathrm{Cftr}^{-1}$ (B6.129-Cftrtm/UNC; C57BL/6J-Cftrtm/UNC) mice and mounted at full thickness in standard Ussing chambers $\left(0.25 \mathrm{~cm}^{2}\right.$ exposed surface area). Intestinal preparations were bathed bilaterally in Krebs bicarbonate Ringers containing (in mM) $115 \mathrm{NaCl}, 2.4 \mathrm{~K}_{2} \mathrm{HPO}_{4}, 0.4 \mathrm{KH}_{2} \mathrm{PO}_{4}, 25$ $\mathrm{NaHCO}_{3}, 1.2 \mathrm{CaCl}_{2}$, and $1.2 \mathrm{MgCl}_{2}(\mathrm{pH} 7.4)$ and gassed with $95 \% \mathrm{O}_{2} / 5 \% \mathrm{CO}_{2}$. Glucose $(10 \mathrm{mM})$ was added to the serosal bath; mannitol (10 mM) was substituted for glucose in the mucosal bath to avoid an inward current resulting from $\mathrm{Na}^{+}$-coupled glucose cotransport (25). Transepithelial short-circuit current $\left(I_{\mathrm{sc}}\right.$, in $\left.\mu \mathrm{Eq} / \mathrm{cm}^{2} / \mathrm{h}\right)$ was measured using an automatic voltage clamp (VCC600; Physiologic Instruments, San Diego, California, USA), and total tissue conductance $\left(G_{t}, \mathrm{mS} / \mathrm{cm}^{2}\right.$ tissue surface area) was determined every 5 minutes by measuring the current deflections resulting from a $5-\mathrm{mV}$ transepithelial pulse and applying Ohm's law. The serosal bath served as ground in all experiments. For experiments measuring the $I_{\mathrm{sc}}$ response to glucose addition or intracellular cAMP stimulation, the jejunal sections were treated by addition of $10 \mathrm{mM}$ glucose to the mucosal bath for 10 minutes or by bilateral addition of $10 \mu \mathrm{M}$ forskolin for 15 minutes, respectively.

Permeability characteristics of the jejunum were estimated by changes in $G_{\mathrm{t}}$ and in the unidirectional mucosal-to-serosal ${ }^{3} \mathrm{H}$-mannitol flux $\left(J_{\text {mannitol }}\right)$ at 1,2 , and 3 hours after intraperitoneal injection in mice treated with saline or $0.2 \mathrm{mg}$ anti-CD3 $\mathrm{mAb}$. After a 30minute equilibration, a 30-minute flux period was initiated and flux rates were calculated from aliquots taken at the beginning and end of the flux period. Radioactivity was quantified by liquid scintillation spectroscopy (Packard Instrument Co., Meriden, Connecticut, USA), and flux was calculated as previously described (25). Net $\mathrm{Na}^{+}$flux was measured as the difference between the unidirectional mucosal-to-serosal $\left(J_{\mathrm{ms}}\right)$ and serosal-to-mucosal $\left(J_{\mathrm{sm}}\right)$ fluxes $\left(J_{\mathrm{net}}=J_{\mathrm{ms}}-J_{\mathrm{sm}}\right)$ of ${ }^{22} \mathrm{Na}$, as previously described (26). Electroneutral $\mathrm{Na}^{+}$ absorption resulting from $\mathrm{Na}^{+} / \mathrm{H}^{+}$exchange activity was estimated by measurement of the unidirectional mucosal-to-serosal flux of ${ }^{22} \mathrm{Na}\left(\mathrm{Jms}^{\mathrm{Na}+}\right)$ across paired jejunal sections $\left(G_{t}\right.$ within $\left.10 \%\right)$ in the presence or absence of $100 \mu \mathrm{M} 5$-( $N$-ethyl- $N$-isopropyl) amiloride (EIPA), as previously described (26). EIPA-sensitive fluxes were calculated using the formula: EIPA-sensitive $J_{\mathrm{ms}^{\mathrm{Na}}}{ }^{\mathrm{Na}}=$ vehicle (DMSO) $J_{\mathrm{ms}}{ }^{\mathrm{Na}+}-\operatorname{EIPA} J_{\mathrm{ms}}{ }^{\mathrm{Na}+}$.

Statistical analysis. The Student's $t$ test was used to evaluate differences between the control and experimental groups. When more than two groups were compared, a one-way ANOVA followed by a post hoc Tukey's $t$ test was used to evaluate differences. Differences were considered significant with $P$ values of less than 0.05 .

\section{Results}

Anti-CD3-induced enteropooling. To examine the effects of $T$ cell activation on intestinal fluid and electrolyte losses, mice were given systemic injections of anti-CD3 (2C11) $\mathrm{mAb}$. Within 1-3 hours of in vivo $\mathrm{T}$ cell stimulation, mice developed watery stools and rectal prolapse. Examination of the small intestine revealed fluid-filled loops of duodenum, jejunum, and ileum. To quantify the volume of fluid produced (enteropooling), random segments of jejunum were isolated, tied at the ends, and removed for measurement of the wt/l ratio (23). T cell stimulation increased the wt/l ratios of jejunal segments by $33 \%$ at 1 hour and more than $50 \%$ at 3 hours (Figure 1a). Levels gradually declined to base line by 6 hours after anti-CD3 $\mathrm{mAb}$ injection. These results indicate that in vivo $\mathrm{T}$ cell activation induces a self-limited accumulation of fluid in the small intestine that is associated with watery diarrhea.

The role of TNF and IFN- $\gamma$ in T cell-induced diarrhea. TNF and IFN- $\gamma$ can be detected at relatively high levels in the serum within 1 hour of in vivo $T$ cell activation (20-22). To determine the role of IFN- $\gamma$ and TNF in T cellinduced diarrhea, mice were treated with neutralizing $\mathrm{mAb}$ to these cytokines prior to injection of anti-CD3 $\mathrm{mAb}$. Anti-TNF mAb inhibited more than $75 \%$ of the increase in intestinal fluid induced by anti-CD3 (Figure $1 b)$. By comparison, IFN- $\gamma$ blockade reduced the effect of anti-CD3 mAb on intestinal fluid by about $30 \%$. Taken together, these data suggest that TNF largely mediates $\mathrm{T}$ cell-induced diarrhea, and that IFN- $\gamma$ may play a minor role. The TNF- and IFN- $\gamma$-neutralizing antibodies by themselves had no effect on enteropooling (data not shown).

To further explore the relationship between $\mathrm{T}$ cellinduced cytokines and diarrhea, gene knockout mice were used. Responses to anti-CD3 $\mathrm{mAb}$ were reduced by $50 \%$ in TNFR-1 knockout $\left(\right.$ TNFR-1 $\left.{ }^{--}\right)$mice $(P<0.01$; Figure 1c). Interestingly, no difference was detected between wild-type and $I F N-\gamma^{\prime}-$ mice in response to anti-CD3 treatment. Although these data suggest that IFN- $\gamma$ plays little if any role in T cell-induced diarrhea, it is possible that 


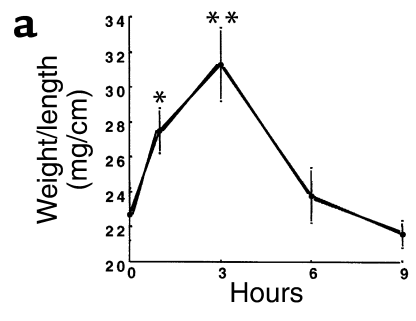

b

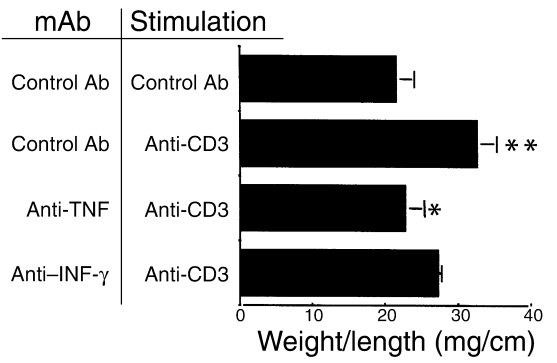

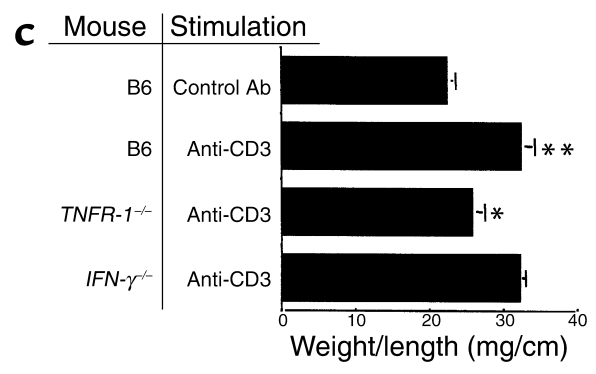

\section{Figure 1}

(a) Time course of effect of anti-CD3 mAb on jejunal wt/l ratio. Mice were injected with $0.2 \mathrm{mg}$ anti-CD3 mAb at time 0 . Loop wt/l ratios were measured after varying times. Values are means \pm SE for six determinations. (b) Effect of anti-TNF and anti-IFN- $\gamma$ antibodies on jejunal wt/l ratios at 3 hours. Mice were injected simultaneously with $0.2 \mathrm{mg}$ control or anti-CD3 mAb along with neutralizing mAb to TNF or IFN- $\gamma$. (c) Control or anti-CD3 $\mathrm{mAb}$ was injected in C57BL/ 6 or in TNFR- 1 or IFN- $\gamma$ knockout mice. Weight-to-length ratios were determined after 3 hours. Values are means \pm SE for six determinations in each group. In all cases, ${ }^{*} P<0.05,{ }^{*} P<0.01$ by comparison using ANOVA. In (a), all comparisons were with 0 -time control. In (b) and (c), control mAb-treated, anti-CD3-stimulated mice were initially compared with control mAb-treated, unstimulated controls. In (b), results in anti-TNF mAb and anti-IFN- $\gamma$-treated, anti-CD3-stimulated mice were compared with control mAb-treated, anti-CD3-stimulated mice. In (c), results in anti-CD3-stimulated TNFR-1-1- and IFN- $\gamma^{-1}$ mice were compared with anti-CD3-stimulated B6 mice. The data indicate that TNF but not IFN- $\gamma$ inhibition prevented anti-CD3-induced diarrhea.

redundant (e.g., TNF-mediated) pathways may have compensated for the absence of IFN- $\gamma$ in these mice.

Previous studies suggest that TNF and possibly IFN- $\gamma$ play a role in $\mathrm{T}$ cell-induced diarrhea in mice (20-22). To examine the isolated effects of these cytokines on intestinal fluid, we treated mice with injection of exogenous TNF and IFN- $\gamma$ (Figure 2a). A clear dose effect was detected for TNF-induced intestinal fluid accumulation (Figure $2 \mathrm{~b}$ ). By comparison, only a minor effect was detected for IFN- $\gamma$ despite administration of 10,000 U per mouse.

$T$ cell activation results in downregulation of intestinal $\mathrm{Na}^{+} / \mathrm{K}^{+}$-ATPase. Previous studies $(16-18)$ suggest that diarrhea in immune-mediated bowel disorders is associated with decreased $\mathrm{Na}^{+} / \mathrm{K}^{+}$-ATPase activity. To examine the effect of in vivo $\mathrm{T}$ cell activation on $\mathrm{Na}^{+} / \mathrm{K}^{+}$ATPase activity, mice were given control or anti-CD3 $\mathrm{mAb}$ and jejunal tissues were isolated. Compared with controls, anti-CD3 mAb treatment decreased mucosal $\mathrm{Na}^{+} / \mathrm{K}^{+}$-ATPase activity by almost $40 \%$ from 863 to 543 $\mathrm{nmol} \mathrm{PNP} / \mathrm{mg}$ protein/hour $(P<0.01$; Figure $3 \mathrm{a})$. In contrast, protein levels of $\alpha$ and $\beta$ subunits of epithelial $\mathrm{Na}^{+} / \mathrm{K}^{+}$-ATPase were unchanged (Figure $3 \mathrm{e}$ ).

The role of TNF and IFN- $\gamma$ in T cell-induced downregulation of $\mathrm{Na}^{+} / \mathrm{K}^{+}$-ATPase. To address the role of cytokines in the downregulation of $\mathrm{Na}^{+} / \mathrm{K}^{+}$-ATPase activity induced by in vivo $T$ cell activation, anti-CD3 $\mathrm{mAb}$ was administered to mice pretreated with control or TNF-neutralizing $\mathrm{mAb}$ or to mice deficient in TNFR- 1 or IFN- $\gamma$. Anti-TNF mAb reduced the effect of $\mathrm{T}$ cell activation on $\mathrm{Na}^{+} / \mathrm{K}^{+}$-ATPase activity by $45 \%$ compared with that in controls (Figure 3a). Similarly, in TNFR-1-deficient mice, the effect of anti$\mathrm{CD} 3 \mathrm{mAb}$ on $\mathrm{Na}^{+} / \mathrm{K}^{+}$-ATPase activity was diminished by $62 \%$ (Figure $3 \mathrm{c}$ ). Taken together, these data suggest that TNF plays a significant role in the downregulation of $\mathrm{Na}^{+} / \mathrm{K}^{+}$-ATPase detected in intestinal inflammation.

Compared with TNF, IFN- $\gamma$ had relatively little effect on $\mathrm{T}$ cell-induced downregulation of $\mathrm{Na}^{+} / \mathrm{K}^{+}$-ATPase. In mice pretreated with anti-IFN- $\gamma$, the effect of T cell activation on $\mathrm{Na}^{+} / \mathrm{K}^{+}$-ATPase activity was reduced by only
$21 \%$ compared with that in control mice pretreated with GL113 (Figure 3b). Likewise, $\mathrm{Na}^{+} / \mathrm{K}^{+}$-ATPase activity was decreased to a similar degree in IFN- $\gamma$ knockout mice compared with C57BL/6 controls (Figure 3c). The difference between control $\mathrm{mAb}$ and anti-IFN- $\gamma \mathrm{mAb}$ treatment prior to anti-CD3 was not statistically significant using an ANOVA with a Bonferroni correction.

To address the direct effect of cytokine on $\mathrm{Na}^{+} / \mathrm{K}^{+}-$ ATPase, mice were injected with exogenous TNF or IFN- $\gamma$. Intestinal $\mathrm{Na}^{+} / \mathrm{K}^{+}$-ATPase activity was measured in mice treated with a dose of TNF $(8 \mu \mathrm{g})$ that induced levels of enteropooling similar to those induced by 0.2 $\mathrm{mg}$ anti-CD3 mAb. Exogenous TNF reduced intestinal $\mathrm{Na}^{+} / \mathrm{K}^{+}$-ATPase activity by $49 \%$ from control levels (Figure $3 \mathrm{~d}$ ). In contrast, treatment with relatively high levels of exogenous IFN- $\gamma(10,000 \mathrm{U})$ failed to affect $\mathrm{Na}^{+} / \mathrm{K}^{+}$-ATPase activity (Figure $3 \mathrm{~d}$ ).

To determine whether decreased activity after antiCD3 mAb treatment was due to decreased abundance of either the $\alpha$ or the $\beta$ subunit, Western blot analysis of these proteins was determined. The effects of antiCD3 mAb as well as TNF and IFN- $\gamma$ on the $\mathrm{Na}^{+} / \mathrm{K}^{+}-$ ATPase subunits are presented in Figure $3 e$. At 3 hours, none of the treatments downregulated either the $\alpha$ or $\beta$ subunit. Therefore, the decreased activity could be due to chemical modification of one or both subunits.

Ion transport alterations in anti-CD3-treated mice. $\mathrm{T}$ cell activation produces profound alterations in ion transport of the intestine $(22,27)$. Downregulation of $\mathrm{Na}^{+} / \mathrm{K}^{+}$ATPase would be anticipated to impinge on nearly every active transport pathway of the cell, similar to the effects of ouabain. The basolateral pump is required to maintain low intracellular $\mathrm{Na}^{+}$and, thereby, provide the electrochemical driving force for most secondary active transport pathways. Alterations in ion transport pathways induced by $\mathrm{T}$ cell activation were investigated using isolated jejunal sections from mice treated with anti-CD3 $\mathrm{mAb}$ for 1, 2, or 3 hours. Basal bioelectric parameters of intestinal sections are shown in Figure 4. As compared 


\section{a Stimulation}

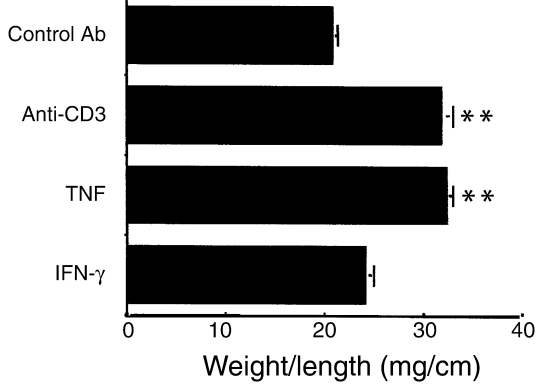

b

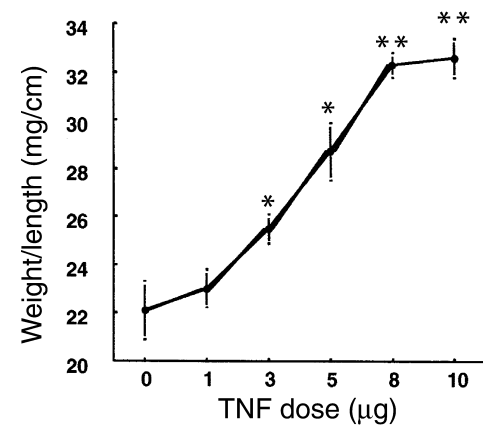

with the saline-injected control jejuna, the $I_{\mathrm{sc}}$ (an index of transcellular electrogenic ion transport in jejunal sections) at all time points was not different in the anti-CD3 $\mathrm{mAb}$-treated jejuna (Figure 4). In contrast, $G_{\mathrm{t}}$ was significantly increased over control at the 1-hour and 2-hour time points, but normalized by 3 hours (Figure 4). It should be emphasized that in a relatively leaky epithelium like the jejunum, the conductance of the paracellular pathway represents approximately $90 \%$ of the $G_{t}(28)$. The
Effect of TNF or IFN- $\gamma$ on wt/I ratios. (a) Mice were injected with control antibody, anti-CD3 mAb, TNF, or IFN- $\gamma$. Jejunal wt/I ratios were measured at 3 hours. Values are means \pm SE for six determinations. (b) Dose-dependence of TNF effect. Mice were injected with varying amounts of TNF, and jejunal wt/l ratios were measured at 3 hours. Values are means \pm SE for six determinations in each group or each TNF dose. ${ }^{*} P<0.05,{ }^{*} P<0.01$ compared with control antibody in $\mathbf{a}$ and 0 TNF in $\mathbf{b}$ by ANOVA.

increase in paracellular permeability detected by the $G_{t}$ measurements was mirrored by an increase in passive ${ }^{3} \mathrm{H}-$ mannitol flux $\left(J_{\text {mannitol }}\right)$, although the changes were only significant at the 1-hour time point (Figure 4). These findings indicate that $\mathrm{T}$ cell activation produces an early (1-2 hours) increase in the paracellular conductance of the jejunum but does not elicit an effect on electrogenic ion transport that persists during in vitro measurements.

An increase in paracellular permeability of the antiCD3 mAb-treated mice may account for a portion of intestinal fluid accumulation; however, it does not fully explain the maximal enteropooling that occurs at 3 hours after injection. Since the preceding studies indicated that $\mathrm{T}$ cell activation does not produce an overt anion secretory response, we investigated the effect of anti-CD3 mAb treatment on $\mathrm{Na}^{+}$absorption across the jejunum. In the absence of nutrient solutes, sodium is absorbed in the small intestine primarily by the activity of luminal membrane $\mathrm{Na}^{+} / \mathrm{H}^{+}$exchangers, e.g., NHE3 and NHE2 $(29,30)$. Therefore, changes in the magnitude of this process were investigated by measurement of isotopic $\mathrm{Na}^{+}$flux across intestine from control and anti-CD3 mAb-injected mice (3 hours after injection). As shown in Table 1, anti-CD3 mAb treatment nearly

\section{Figure 3}

(a-d) Effect of anti-CD3 mAb on $\mathrm{Na}^{+} / \mathrm{K}^{+}$-ATPase activity. Mice were injected with control or antiCD3 mAb and enzyme activity measured in jejunum isolated 3 hours later. Values are means \pm SE for four to six determinations in each group. Results in unstimulated mice treated with antiTNF (a) or anti-IFN- $\gamma(\mathbf{b})$ mAbs were not different from control mAb-treated, unstimulated mice (data not shown). In (a) and (b), results in control mAb-treated, anti-CD3-stimulated mice were compared with unstimulated mice. Results of anti-cytokine-treated, anti-CD3-stimulated mice were compared with control mAb-treated, anti-CD3-stimulated mice. In (c), data in B6, anti-CD3-stimulated mice were compared with B6, unstimulated mice and results in anti-CD3stimulated, TNFR-1 ${ }^{-1-}$ and IFN- $\gamma^{-1}$ mice were compared with B6, anti-CD3-stimulated mice. In (d), results in anti-CD3 mAb-stimulated, TNFtreated and IFN- $\gamma$-treated mice were compared with control mAb-treated mice. (e) Effect of antiCD3 mAb on abundance of $\mathrm{Na}^{+} / \mathrm{K}^{+}$-ATPase $\alpha$ and $\beta$ subunits. Microsomal membranes were isolated and analyzed on SDS-PAGE, and Western blots were performed using $\mathrm{mAb}$ to the $\alpha$ and $\beta$ subunits. ${ }^{*} P<0.05,{ }^{*} P<0.01$ compared with control by ANOVA. a

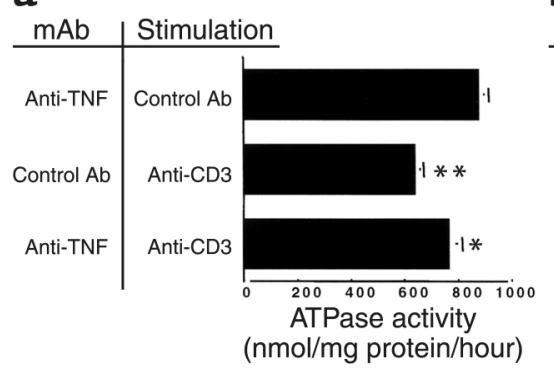

C

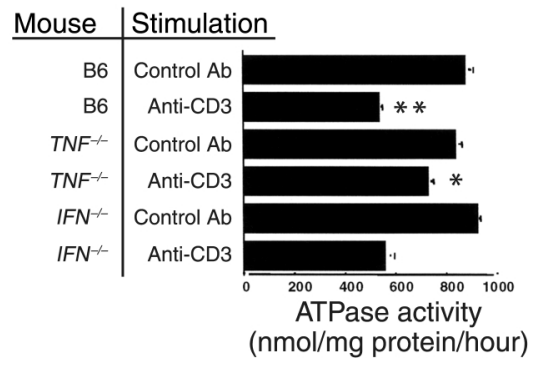

b

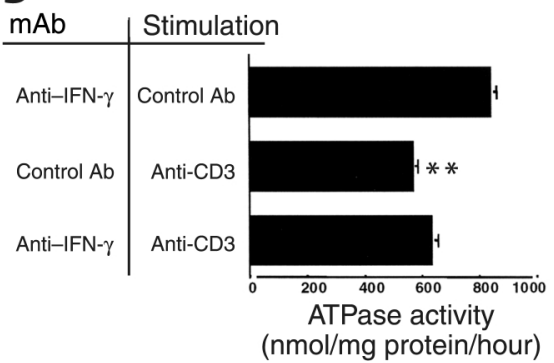

d Stimulation

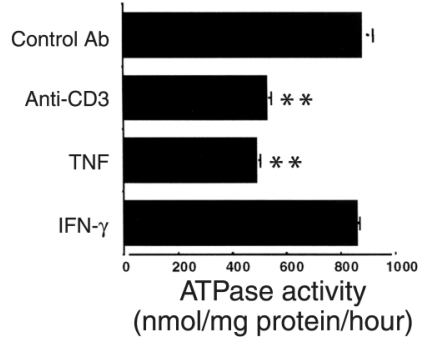

e

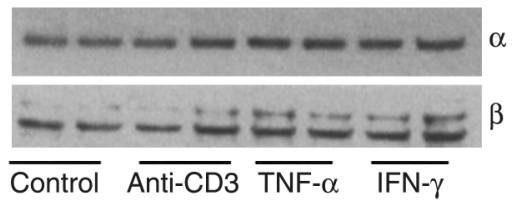




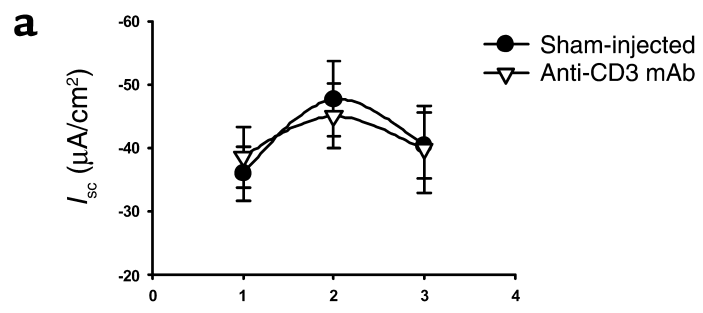

b
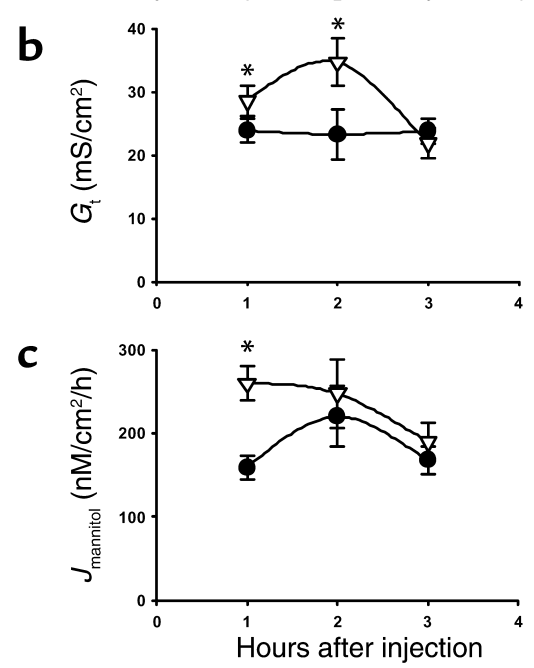

abolished net $\mathrm{Na}^{+}$absorption, primarily as a result of a decrease in the mucosal-to-serosal (absorptive) $\mathrm{Na}^{+}$flux. To verify that the effect of anti-CD3 mAb treatment on net $\mathrm{Na}^{+}$absorption was due to inhibition of the apical membrane $\mathrm{Na}^{+} / \mathrm{H}^{+}$exchangers, the magnitude of mucosal-to-serosal $\mathrm{Na}^{+}$flux sensitive to the $\mathrm{Na}^{+} / \mathrm{H}^{+}$ exchange inhibitor EIPA was measured in a separate series of experiments (26). Three hours of treatment with anti-CD3 mAb inhibited almost $90 \%$ of the EIPAsensitive $\mathrm{Na}^{+}$absorption across the jejunum (Figure 5a). Next, to evaluate the effect of $\mathrm{T}$ cell activation on $\mathrm{Na}^{+}$coupled nutrient transport, the $I_{\mathrm{sc}}$ response to mucosal addition of $10 \mathrm{mM}$ glucose was measured. The Na-coupled glucose current was reduced by $55 \%$ in the anti$\mathrm{CD} 3 \mathrm{mAb}$-treated intestine (Figure $5 \mathrm{~b}$ ). The above findings were consistent with inhibition of $\mathrm{Na}^{+}$-absorptive processes, an effect probably secondary to a decrease in $\mathrm{Na}^{+} / \mathrm{K}^{+}$-ATPase activity resulting from $\mathrm{T}$ cell activation. To further examine the effect of anti-CD3 mAb treatment on secondary active transport, we measured the anion secretory response during acute stimulation of intracellular cAMP. As shown in Figure $5 \mathrm{c}$, the $I_{\mathrm{sc}}$ response to forskolin was reduced by nearly $70 \%$ in the
anti-CD3 $\mathrm{mAb}$-treated intestine, demonstrating that $\mathrm{T}$ cell activation inhibits stimulated anion secretion.

In vitro studies suggested that diarrhea induced by $\mathrm{T}$ cell activation does not induce active anion secretion. To test this hypothesis in vivo, effects of anti-CD3 mAb treatment on enteropooling in mice with gene-targeted deletion of CFTR were examined. CFTR is a final common pathway for anion secretion regulated by intracellular cyclic nucleotides or $\mathrm{Ca}^{2+}$ in the murine small intestine (26). However, anti-CD3 mAb treatment increased fluid accumulation in the small intestine of the CFTR-null mice to approximately the same extent as it did in wildtype mice (Figure 6). Note that the base-line fluid accumulation in the saline-injected CFTR-null intestine exceeds that measured in the saline-injected wild-type mice, an effect that may be due to the older age of the CFTR-null mice (8-14 weeks). The in vitro bioelectric parameters of the CFTR-null intestine following antiCD3 mAb treatment were also investigated and are shown in Figure 6, b-d. Interestingly, anti-CD3 treatment induced a small increase in $I_{\mathrm{sc}}$, suggesting novel activation of a minor conductive pathway (e.g., a separate apical channel for $\mathrm{Cl}^{-}$secretion). Perhaps more importantly, both $G_{\mathrm{t}}$ and $J_{\text {mannitol }}$ were significantly increased in the CFTR-null intestine, as was previously shown in the wildtype intestine. It is interesting to note that increased intestinal permeability was sustained at 3 hours after injection in the CFTR-null intestine, in contrast to the wild-type intestine (compare with Figure $4, J_{\text {mannitol }}$ ), a result suggesting that CFTR activity is involved in the normalization of paracellular permeability in the wild-type intestine following $\mathrm{T}$ cell activation.

To determine whether increased salivary or gastric secretions may account for the enteropooling, a surgical model was created in which the intestinal contents were diverted at the duodenal-jejunal junction. A heterotopic small bowel transplantation was performed. In these mice the proximal small bowel is made into an ostomy and the efferent limb of the bowel is anastomosed into the host's distal small bowel. These mice were injected with either control or anti-CD3 $\mathrm{mAb}$, and

Table 1

Unidirectional and net $\mathrm{Na}^{+}$flux across the jejunum of sham-injected and anti-CD3 antibody-injected mice 3 hours after injection

\begin{tabular}{|c|c|c|c|c|c|}
\hline & $\begin{array}{c}\mathrm{ms} \\
\mu \mathrm{Eq} / \mathrm{cm}^{2} / \mathrm{h}\end{array}$ & $\begin{array}{c}J^{\mathrm{Na}^{+}} \\
\mathrm{sm} \\
\mu \mathrm{Eq} / \mathrm{cm}^{2} / \mathrm{h}\end{array}$ & $\begin{array}{c}\text { net } \\
\mu \mathrm{Eq} / \mathrm{cm}^{2} / \mathrm{h}\end{array}$ & $\begin{array}{c}I_{\mathrm{sc}} \\
\mu \mathrm{Eq} / \mathrm{cm}^{2} / \mathrm{h}\end{array}$ & $\begin{array}{c}G_{\mathrm{t}} \\
\mathrm{mS} / \mathrm{cm}^{2}\end{array}$ \\
\hline Sham & $22.4 \pm 1.4$ & $17.0 \pm 0.9$ & $5.4 \pm 0.7$ & $-0.6 \pm 0.2$ & $33.4 \pm 1.2$ \\
\hline Anti-CD3 & $16.0 \pm 1.3^{\mathrm{A}}$ & $15.9 \pm 1.6$ & $0.1 \pm 0.8^{\mathrm{A}}$ & $-0.3 \pm 0.1$ & $29.8 \pm 1.4^{\mathrm{A}}$ \\
\hline
\end{tabular}

ASignificantly different from sham-injected, $P<0.05$. 
a

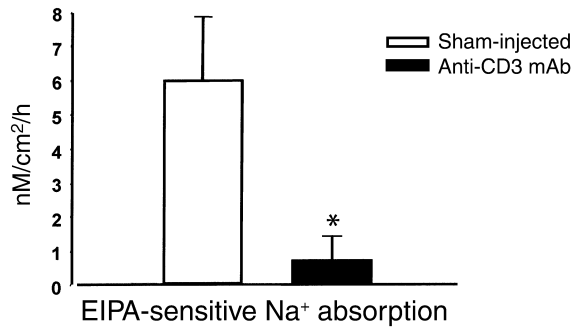

b

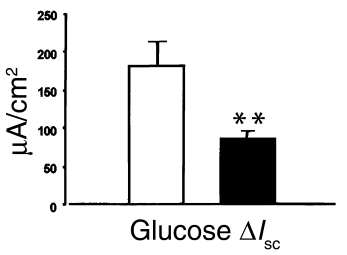

C

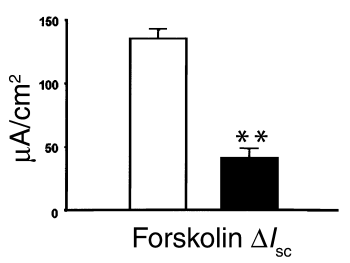

Figure 5

Effect of anti-CD3 mAb on $\mathrm{Na}^{+}$absorption and anion secretion across murine jejunum. Mice were injected with PBS (Sham-injected) or 0.2 $\mathrm{mg}$ anti-CD3 mAb 3 hours before sacrifice. Jejunal sections were mounted in Ussing chambers for measurement of $I_{\mathrm{sc}}$ and ${ }^{22} \mathrm{Na}$ flux measurements. (a) Mucosal-to-serosal ${ }^{22} \mathrm{Na}$ flux sensitive to $100 \mu \mathrm{M}$ $\operatorname{EIPA}\left(n=10\right.$ sections from six mice). (b) $I_{\text {sc }}$ response to addition of 10 $\mathrm{mM}$ glucose in mucosal bath (15 minutes) to stimulate $\mathrm{Na}^{+}$-coupled glucose transport ( $n=12$ sections from six mice). (c) $I_{\text {sc }}$ response to addition of $10 \mu \mathrm{M}$ forskolin in bathing solutions (10 minutes) to stimulate cAMP-dependent anion secretion $(n=11$ sections from six mice). Values are means $\pm \mathrm{SE}$. ${ }^{*} P<0.05,{ }^{*} P<0.1 \mathrm{vs}$. sham-injected.

enteropooling was measured. Fluid accumulation was not different in jejunal loops between the two groups. Weight-to-length ratios at 3 hours were $22 \pm 2$ and $23 \pm 2$ in the sham-operated and intestinal-diversion mice, respectively, after injection of control $\mathrm{mAb}$. After anti$\mathrm{CD} 3 \mathrm{mAb}$, these values increased to $34 \pm 3$ and $36 \pm 2$ in the two groups, respectively. Thus the fluid accumulated in the intestinal lumen was not derived from secretions of proximal sections of the intestine but arose from transmucosal fluid shifts.

\section{Discussion}

Using an in vivo model, we examined the mechanism(s) of fluid loss (diarrhea) induced by $\mathrm{T}$ cell activation by anti-CD3 $\mathrm{mAb}$. Our results suggest that $\mathrm{T}$ cell-induced TNF production induces fluid accumulation in the small bowel by downregulating the activity of epithelial $\mathrm{Na}^{+} / \mathrm{K}^{+}$-ATPase. $\mathrm{T}$ cell-induced diarrhea has been attributed to several cytokines produced by $\mathrm{T}$ cells, including TNF, IFN- $\gamma$, IL-1, IL-2, IL-3, IL-6, IL-8, and IL-10 (30-32). The data presented herein suggest that among these, TNF plays a crucial role. In our studies, we observed a dose-dependent fluid accumulation following direct injection of mice with TNF. Clinically, blocking TNF with mAb's (Infliximab) has been known to prevent diarrhea symptoms in patients with $\operatorname{IBD}(2$, 33). Similarly, we found that in mice, blocking TNF prior to $\mathrm{T}$ cell activation prevented fluid accumulation almost completely. Results from experiments were also significant in mice deficient in TNFR-1 (p55). Anti-

CD3 mAb-induced fluid accumulation in these mice was lower than in C57BL/ 6 controls, but not as low as in C57BL/6 mice pretreated with anti-TNF $\mathrm{mAb}$. This slight disparity may reflect the role of another diarrheaproducing cytokine in the knockout mice, perhaps IL-1, as an adaptation to the absence of TNF.

Anti-CD3 mAb-induced fluid accumulation in IFN- $\gamma$ knockout mice was similar to that in C57BL/6 mice, whereas blocking IFN- $\gamma$ with $\mathrm{mAb}$ prior to anti-CD3 treatment slightly reduced diarrhea. These data suggest that IFN- $\gamma$ does not play a major role in T cell-induced diarrhea. These results were surprising, as in vitro experiments suggest that this cytokine regulates paracellular permeability $(34,35)$. It should be noted that the effects of IFN- $\gamma$ both in vitro and in vivo require many hours to be manifest. The permeability changes observed in the present model, however, occurred rapidly and may indicate a different mechanism. Lastly, it is possible that IFN- $\gamma$ acts synergistically with TNF, as reported in other biological processes $(36,37)$, for example by enhancing synthesis of TNF or other diarrhea-inducing cytokines. Thus, further studies may be needed to fully examine the complex role of IFN- $\gamma$ in immune-mediated diarrhea.

At least three mechanisms might account for the final step in the development of diarrhea in inflammatory intestinal conditions: (a) loss of plasma and fluid through the inflamed and ulcerated mucosa, (b) upregulation of secretory proteins, and (c) downregulation of absorptive proteins. Cytokines are thought to contribute to diarrhea by the latter two processes. Various authors have suggested upregulation of $\mathrm{Cl}^{-}$channels in the apical membrane of crypt epithelial cells during inflammatory a

C

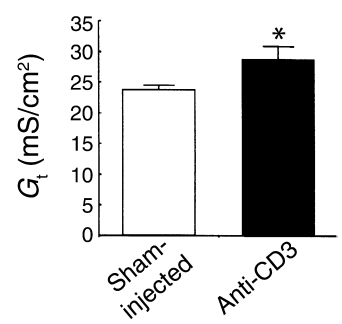

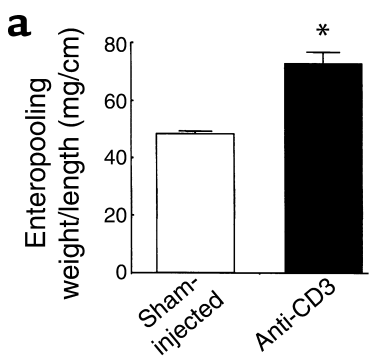

b
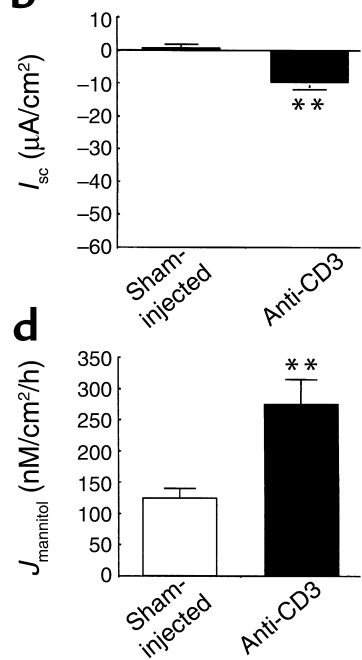

Figure 6

Effect of anti-CD3 mAb in CFTR-deficient mice. Mice were injected with PBS (Sham-injected) or $0.2 \mathrm{mg}$ anti-CD3 mAb 3 hours before sacrifice. (a) Effect on jejunal wt/I ratio. Values are means $\pm \mathrm{SE}$ for three mice in each group. ${ }^{*} P<0.5$ vs. sham-injected. (b-d) Effect of anti-CD3 $\mathrm{mAb}_{\mathrm{sC}}, \mathrm{G}_{\mathrm{t}}$ and $J_{\text {mannitol }}$ of intestine from CFTR-deficient murine jejunum. Values are means \pm SE for seven sections (four mice). ${ }^{*} P<0.05,{ }^{*} P<0.1$ vs. sham-injected. 
conditions, and TNF has been shown to inhibit $\mathrm{Cl}^{-}$ absorption and stimulate $\mathrm{Cl}^{-}$secretion in the human colon (31). Absorption of $\mathrm{Na}^{+}$across the intestine involves the participation of several proteins, including the $\mathrm{Na}^{+} / \mathrm{H}^{+}$exchangers and $\mathrm{Na}^{+} /$nutrient transporters located in the luminal cell membranes. More importantly, absorption requires the active transport of $\mathrm{Na}^{+}$out of the epithelial cells, mediated by the $\mathrm{Na}^{+} / \mathrm{K}^{+}$-ATPase located on the basolateral cell membranes. This transporter consists of two subunits: a $97-\mathrm{kDa} \alpha$ subunit and a 55$\mathrm{kDa} \beta$ subunit. Its phosphatase activity is assigned to the $\alpha$ subunit, while the $\beta$ subunit is thought to prevent the proteolytic degradation of newly synthesized $\alpha$ subunits. Using the $\mathrm{K}^{+}$-stimulated phosphatase assay, we demonstrated significant reductions in $\mathrm{Na}^{+} / \mathrm{K}^{+}$-ATPase activity in jejunal mucosa with anti-CD3 and TNF treatment. The process responsible for reduced pump activity does not appear to decrease protein abundance in the epithelia, since Western blot analysis of both subunits of $\mathrm{Na}^{+} / \mathrm{K}^{+}$-ATPase did not show reduced expression of the protein with either anti-CD3 activation or TNF treatment. This would suggest that a chemical modification of $\mathrm{Na}^{+} / \mathrm{K}^{+}$-ATPase that inactivates the enzyme occurs following $\mathrm{T}$ cell activation. Previous studies from our laboratory as well as other laboratories have demonstrated that nitric oxide may alter barrier function in intestinal epithelial cells and may do so by inhibiting $\mathrm{Na}^{+} / \mathrm{K}^{+}$ATPase $(38,39)$. Interestingly, we found that fluid accumulation in $\mathrm{NOS}^{-/-}$mice was not significantly different from that in control mice (data not shown). Thus, these in vivo data suggest that iNOS-independent signaling pathways decreased $\mathrm{Na}^{+} / \mathrm{K}^{+}$-ATPase activity. In vitro in a cultured thyroid epithelial cell line, TNF inhibits activity and expression of $\mathrm{Na}^{+} / \mathrm{K}^{+}$-ATPase (40); however, the precise mechanisms of inhibition are not known.

The relationship between pump activity and permeability of the tight junctions is poorly understood. Recent studies using the renal epithelial Madin Darby Canine Kidney cell line suggest that $\mathrm{Na}^{+} / \mathrm{K}^{+}$-ATPase activity is required for acute maintenance of tight-junctional permeability (41). The relationship between pump activity and tight-junctional permeability may be influenced by the amount of cell swelling that occurs after pump inhibition and also by how "tight" the occluding junctions are in a particular epithelium. It is also possible that changes in tight-junctional permeability may be mediated by other effects of $\mathrm{T}$ cell activation and TNF production. Using an HT29 colonic epithelial cell line subclone, TNF was shown to decrease the number of intercellular strands on electron micrographs (42). These investigators, however, did not determine the mechanism through which TNF acts and whether these junctional-strand changes might involve changes in $\mathrm{Na}^{+} / \mathrm{K}^{+}$ATPase activity, changes in intracellular $\mathrm{Na}^{+}$, or subsequent stress kinase activation. Decreased numbers of junctional strands have been observed in studies of permeability in ulcerative colitis patients (43), but again, the involvement of inhibition of $\mathrm{Na}^{+} / \mathrm{K}^{+}$-ATPase and TNF has not been investigated.
The hypothesis that fluid accumulation and diarrhea may arise from decreased absorption rather than stimulated secretion is rather novel. Previous studies have documented the secretory effects of a large variety of hormones and neurotransmitters in tissues from healthy animals (reviewed in ref. 1). In contrast, Sandle et al. reported that short-circuit current decreased in inflamed intestine compared with control (44). These data also indicated that tissue inflammation was associated with decreased $\mathrm{Na}^{+}$absorption. In animal models of colitis, both hyporesponsiveness to secretagogues (45) and decreased $\mathrm{Na}^{+}$-absorptive processes $\left(\mathrm{Na}^{+}\right.$-dependent glucose absorption and non-nutrient-dependent $\mathrm{Na}^{+}$and $\mathrm{Cl}^{-}$transport) have been observed $(46,47)$. Similar to the present findings, decreased $\mathrm{Na}^{+} / \mathrm{K}^{+}$-ATPase activity was measured in inflamed intestine (48). Studies with ouabain indicate that inhibition of $\mathrm{Na}^{+} / \mathrm{K}^{+}$-ATPase impairs the ability of enterocytes to maintain an electrochemical gradient, thereby impairing both $\mathrm{Na}^{+}$absorption and $\mathrm{Cl}^{-}$secretion (49). Taken together, these data and our own suggest that $\mathrm{T}$ cell activation reduces $\mathrm{Na}^{+}$ absorption and $\mathrm{Cl}^{-}$secretion in inflamed tissue by TNFmediated inactivation of $\mathrm{Na}^{+} / \mathrm{K}^{+}$-ATPase. It is also possible that other transport proteins may be modified by $\mathrm{T}$ cell activation (e.g., $\mathrm{Na}^{+}-\mathrm{K}^{+}-\mathrm{Cl}^{-}$cotransporter, electrogenic $\mathrm{Na}^{+}$channels [in colon], CFTR), and these effects might contribute to the antiabsorptive and antisecretory effects of activation of $\mathrm{T}$ cells by anti-CD3 mAb. Inhibition of colonic $\mathrm{Na}^{+} / \mathrm{K}^{+}$-ATPase has been noted by different groups in two previous studies in human inflammatory bowel diseases $(50,51)$. In both studies, an inverse relationship of disease activity and $\mathrm{Na}^{+} / \mathrm{K}^{+}$-ATPase activity was noted. More recent studies using a rat model demonstrated IL-1 $1 \beta$-induced decreases in colonic $\mathrm{Na}^{+} / \mathrm{K}^{+}$ATPase activity (52). All of these authors hypothesize that the decreased ATPase activity relates to the diarrheal fluid losses observed in IBD. Thus, previous studies in IBD states have documented that intense mucosal $\mathrm{T}$ cell activation is associated with decreased $\mathrm{Na}^{+} / \mathrm{K}^{+}$-ATPase activity. These observations led us to speculate that intestinal transport effects of IBD may be primarily malabsorptive - i.e., decreased electrolyte and water absorption - rather than secretory. Additionally, recent studies suggest that IBD intestinal mucosa has greater permeability. The present studies also suggest that increases in permeability may contribute to fluid losses in diarrhea. Any fluid lost as a result of increased permeability would also not be reabsorbed, because of the impairment in electrolyte (and thus in fluid) absorption.

In summary, our data suggest that intestinal $\mathrm{T}$ cell activation induces intestinal fluid accumulation through a cytokine-mediated pathway dominated by TNF. We suspect that these effects contribute to mucosal host defense. Enhanced fluid accumulation in the intestine increases bacterial clearance and may be a mechanism whereby $\mathrm{T}$ cell activation impairs tissue invasion and reduces colonization by enteric pathogen. Thus, the results and model described have important implications for the pathophysiology and therapy of 
diarrhea in infectious enteritis, as well as in aberrant states of intestinal inflammation as seen in IBD.

\section{Acknowledgments}

This work was supported by NIH grants DK-54778 and DK-47073 (to T.A. Barrett), DK-38510 (to E.B. Chang), DK-47722 (to E.B. Chang and M.W. Musch), and DK48816 (to L.L. Clarke), and by research grants from the Crohn's and Colitis Foundation of America (to T.A. Barrett and E.B. Chang), the Gastrointestinal Research Foundation of Chicago, and the American Heart Association.

1. Ciancio, M.J., and Chang, E.B. 1992. Epithelial secretory response to inflammation. Ann. NY Acad. Sci. 664:210-221.

2. Baert, F.J., et al. 1999. Tumor necrosis factor-alpha antibody (Infliximab) therapy profoundly down-regulates the inflammation in Crohn's ileocolitis. Gastroenterology. 116:22-28.

3. Bell, S.J., and Kamm, M.A. 2000. Antibodies to tumor necrosis factor alpha as treatment for Crohn's disease. Lancet. 355:858-860.

4. van Dullemen, H.M., et al. 1995. Treatment of Crohn's disease with antitumor necrosis factor chimeric monoclonal antibody (cA2). Gastroenterology. 109:129-135.

5. Casellas, F., et al. 1994. Intraluminal colonic release of immunoreactive tumour necrosis factor in chronic ulcerative colitis. Clin. Sci. (Lond.) 87:453-458.

6. Reinecker, H.C., et al. 1993. Enhanced secretion of tumor necrosis factoralpha, IL-6, and IL-1 beta by isolated lamina propria mononuclear cells from patients with ulcerative colitis and Crohn's disease. Clin. Exp. Immunol. 94:174-181.

7. Lanfranchi, G.A., and Tragnone, A. 1992. Serum and faecal tumour necrosis factor-alpha as marker of intestinal inflammation. Lancet. 33:1053.

8. Stack, W.A., et al. 1997. Randomised controlled trial of CDP571 antibody to tumour necrosis factor-alpha in Crohn's disease. Lancet. 349:521-524.

9. Brown, G.R., et al. 1999. Tumor necrosis factor inhibitor ameliorates murine intestinal graft-versus-host disease. Gastroenterology. 116:593-601.

10. Bowles, M.J., Pockley, P.G., and Wood, R.F. 2000. Effect of anti-LFA-1 monoclonal antibody on rat small bowel allograft survival and circulating leukocyte populations. Transpl. Immunol. 8:75-80.

11. Nilsen, E.M., et al. 1998. Gluten induces an intestinal cytokine response strongly dominated by interferon gamma in patients with celiac disease. Gastroenterology. 115:551-563.

12. Kutukculer, N., and Caglayan, S. 1997. Tumor necrosis factor-alpha and interleukin- 6 in stools of children with bacterial and viral gastroenteritis. J. Pediatr. Gastroenterol. Nutr. 25:556-557.

13. de Silva, D.G., et al. 1993. Concentrations of interleukin 6 and tumour necrosis factor in serum and stools of children with Shigella dysenteriae 1 infection. Gut. 34:194-198.

14. Steinmetz, T., et al. 1988. Phase I study of 24-hour continuous intravenous infusion of recombinant human tumor necrosis factor. J. Biol. Response Mod. 7:421-423.

15. Ewe, K. 1988. Intestinal transport in constipation and diarrhoea. Pharmacology. 36(Suppl.):73-84.

16. Rachmilewitz, D., Karmeli, F., and Sharon, P. 1984. Decreased colonic NaK-ATPase activity in active ulcerative colitis. Isr. J. Med. Sci. 20:681-684.

17. Allgayer, H., et al. 1988. Inverse relationship between colonic $\left(\mathrm{Na}^{+} / \mathrm{K}^{+}\right)$ATPase activity and degree of mucosal inflammation in inflammatory bowel disease. Dig. Dis. Sci. 33:417-422.

18. Ejderhamn, J., Finkel, Y., and Strandvik, B. 1989. Na, K-ATPase activity in rectal mucosa of children with ulcerative colitis and Crohn's disease. Scand. J. Gastroenterol. 24:1121-1125.

19. Tripp, J.H., Muller, D.P., and Harries, J.T. 1980. Mucosal $\left(\mathrm{Na}^{+}-\mathrm{K}^{+}\right)$-ATPase and adenylate cyclase activities in children with toddler diarrhea and the postenteritis syndrome. Pediatr. Res. 4:1382-1386.

20. Ferran, C., et al. 1991. Cascade modulation by anti-tumor necrosis factor monoclonal antibody of interferon-gamma, interleukin 3 and interleukin 6 release after triggering of the CD3/T cell receptor activation pathway. Eur. J Immunol. 21:2349-2353.

21. Ferran, C., et al. 1990. Cytokine-related syndrome following injection of anti-CD3 monoclonal antibody: further evidence for transient in vivo $\mathrm{T}$ cell activation. Eur. J. Immunol. 20:509-515.

22. Radojevic, N., et al. 1999. Characterization of enteric functional changes evoked by in vivo anti-CD3 T cell activation. Am. J. Physiol. 276:R715-R723.

23. Robert, A., Nezamis, J.E., Lancaster, C., Hanchar, A.J., and Klepper, M.S. 1976. Enteropooling assay: a test for diarrhea produced by prostaglandins. Prostaglandins. 11:809-828.

24. Garrahan, P.J., Pouchan, M.I., and Rega, A.F. 1969. Potassium activated phosphatase from human red blood cells. The mechanism for potassium activation. J. Physiol. 202:305-327.

25. Schultz, S.G., and Zalusky, R. 1964. Ion transport in isolated rabbit ileum. I. Short-circuit current and Na fluxes. J. Gen. Physiol. 47:567-584.

26. Gawenis, L.R., et al. 2002. Intestinal NaCl transport in NHE2 and NHE3 knockout mice. Am. J. Physiol. 282:G776-G784.

27. Barrett, T.A., et al. 1992. Differential function of intestinal intraepithelial lymphocyte subsets. J. Immunol. 149:1124-1130.

28. Frizzell, R.A., and Schultz, S.G. 1972. Ionic conductances of extracellular shunt pathway in rabbit ileum: influence of shunt on transmural sodium transport and electrical potential differences. J. Gen. Physiol. 59:318-337.

29. Schultheis, P., et al. 1998. Renal and intestinal absorptive defects in mice lacking the NHE3 $\mathrm{Na}^{+} / \mathrm{H}^{+}$exchanger. Nat. Genet. 19:282-285.

30. Maher, M.M., Gontarek, J.D., Bess, R.S., Donowitz, M., and Yeo, C.J. 1997. The $\mathrm{Na} / \mathrm{H}$ exchange isoform NHE3 regulates basal canine ileal $\mathrm{Na}$ absorption in vivo. Gastroenterology. 112:174-183.

31. Schmitz, H., et al. 1996. Tumor necrosis factor-alpha induces $\mathrm{Cl}^{-}$and $\mathrm{K}^{+}$ secretion in human colon driven by prostaglandin E2. Am. J. Physiol. 271:G669-G674.

32. Yu, L.C., and Perdue, M.H. 2000. Immunologically mediated transport of ions and macromolecules. Ann. NY Acad. Sci. 915:247-259.

33. Evans, R.C., et al. 1997. Treatment of ulcerative colitis with an engineered human anti-TNFalpha antibody CDP571. Aliment. Pharmacol. Ther. 11:1031-1035.

34. Rocha, F., et al. 2001. IFN- $\gamma$ downregulates expression of $\mathrm{Na}^{+} / \mathrm{H}^{+}$exchangers NHE2 and NHE3 in rat intestine and human Caco2/bbe cells. Am.J. Physiol. Cell Physiol. 280:C1224-C1232.

35. Colgan, S.P., et al. 1994. Interferon-gamma induces a cell surface phenotype switch on T84 intestinal epithelial cells. Am. J. Physiol. 274:C586-C594.

36. Schuerer-Maly, C.C., Eckmann, L., Kagnoff, M.F., Falco, M.T., and Maly, F.E. 1994. Colonic epithelial cell lines as a source of interleukin-8: stimulation by inflammatory cytokines and bacterial lipopolysaccharide. Immunology. 81:85-91.

37. Suk, K., et al. 2001. IFN gamma/TNF alpha synergism as the final effector in autoimmune diabetes: a key role for STAT/IFN regulatory factor1 in pancreatic beta cell death. J. Immunol. 166:4481-4489.

38. Unno, M., Menconi, M.J., Smith, M., and Fink, M.F. 1995. Nitric oxide mediates interferon-gamma-induced hyperpermeability in cultured human intestinal epithelial monolayers. Crit. Care Med. 23:1170-1176.

39. Sugi, K., Musch, M.W., Field, M., and Chang, E.B. 2001. Inhibition of $\mathrm{Na}^{+}, \mathrm{K}^{+}$-ATPase by interferon gamma down-regulates intestinal epithelial transport and barrier function. Gastroenterology. 120:1393-1403.

40. Pekary, A.E., Levin, S.R., Johnson, D.G., Berg, L., and Hershman, J.M. 1997. Tumor necrosis factor-alpha (TNF-alpha) and transforming growth factor-beta 1 (TGF-beta 1) inhibit the expression and activity of $\mathrm{Na}^{+} / \mathrm{K}^{+}$ATPase in FRTL-5 rat thyroid cells. J. Interferon Cytokine Res. 17:185-195.

41. Rajasekaran, S.A., et al. 2001. Na, K, ATPase activity is required for formation of tight junctions, desmosomes, and induction of polarity in epithelial cells. Mol. Biol. Cell. 12:3717-3732.

42. Schmitz, H., et al. 1998. Tumor necrosis factor alpha reduces tight junction complexity in HT-29/B6 colonic monolayers. Gastroenterology. 114:A414. (Abstr.)

43. Schmitz, H., et al. 1999. Altered tight junction structure contributes to the impaired epithelial barrier function in ulcerative colitis. Gastroenterology. 116:301-309.

44. Sandle, G.I., et al. 1990. Cellular basis for defective electrolyte transport in inflamed human colon. Gastroenterology. 99:97-105.

45. Bell, C.J., Gall, D., and Wallace, J.L. 1995. Disruption of colonic electrolyte transport in experimental colitis. Am.J. Physiol. 268:G622-G630.

46. Sundaram, U., Wisel, S., Rajendran, V., and West, A.B. 1997. Mechanism of inhibition of $\mathrm{Na}^{+}$-glucose cotransport in the chronically inflamed rabbit ileum. Am. J. Physiol. 273:G913-G919.

47. Sundaram, U., and West, A.B. 1997. Effect of chronic inflammation on electrolyte transport in rabbit ileal villus and crypt cells. Am. J. Physiol. 272:G732-G741.

48. Wild, G.E., and Thomson, A.B. 1995. $\mathrm{Na}(+)-\mathrm{K}(+)$-ATPase alpha 1- and beta 1-mRNA and protein levels in rat small intestine in experimental ileitis. Am. J. Physiol. 269:G666-G675.

49. Binder, H.J., and Sandle, G.I. 1987. Electrolyte absorption and secretion in the mammalian colon. In Physiology of the gastrointestinal tract. L.R. Johnson, editor. Raven Press. New York, New York, USA. 1389-1418.

50. Ejderhamn, J., Finkel, Y., and Strandvik, B. 1989. Na,K-ATPase activity in rectal mucosa of children with ulcerative colitis. Scand. J. Gastroenterol. 24:1121-1125.

51. Allgayer, H., et al. 1988. Inverse relationship between colonic $\left(\mathrm{Na}^{+-} \mathrm{K}+\right)-$ ATPase activity and degree of mucosal inflammation in inflammatory bowel disease. Dig. Dis. Sci. 33:417-422.

52. Kreydiyyeh, S.I., and Al-Sadi, R. 2002. The mechanism by which interleukin-1 beta reduces net fluid absorption from the rat colon. Eur. Cytokine Netw. 13:358-363. 